\title{
EVALUATION OF PROBIOTIC MICROENCAPSULATION IN A PREBIOTIC MIXTURE WITH COFFEE EXTRACT
}

\author{
Angela María Ormaza Zapata ${ }^{1}$, Félix Octavio Díaz Arango ${ }^{2}$, Sneyder Rodríguez-Barona ${ }^{3}$ \\ (Received: July 18, 2019; accepted: September 06, 2019)
}

\begin{abstract}
The objective in the present study was to evaluate coffee extract as an encapsulant material, when mixed with prebiotic carbohydrates, in order to obtain a coffee-based, non-dairy probiotic beverage. Six coffee extract formulations were evaluated with maltodextrin and inulin, in various proportions, for the obtaining of microcapsules with the probiotic strain L. casei ATCC 393, by way of spray drying. The best formulations encountered were MD-INU:EXT (50:50) and EXT:Water (50:50), which were spray dried, for increased viability, elevated wettability and solubility, low hygroscopicity, and adequate morphology for this type of powdered product. The formulation was composed of maltodextrin, inulin, and coffee extract, and MD-INU:EXT (50:50) presented the best physicochemical and viability characteristics. The potential of coffee extract was proven as a wall material in microencapsulated, non-dairy, highly acidic, probiotic products. Optimal viability was achieved, in the order of $1 \times 10^{6} \mathrm{CFU} / \mathrm{mL}$, for both selected formulations, which maintained functional potential for up to 11 weeks of storage.
\end{abstract}

Index terms: Probiotic, prebiotic, coffee, microencapsulation, extract.

\section{AVALIAÇÃO DA MICROENCAPSULAÇÃO DE UM PROBIÓTICO EM UMA MISTURA PREBIÓTICA COM EXTRATO DE CAFÉ}

\begin{abstract}
RESUMO: O objetivo no presente estudo foi avaliar o extrato de café como um material encapsulante misturado com carboidratos prebióticos para obter uma bebida à base de café probiótico não lácteo. Seis formulações de extrato de café com maltodextrina e inulina foram avaliadas em diferentes proporções para obter microcápsulas da cepa probiótica $L$. casei ATCC 393 por secagem por pulverização. As melhores formulações encontradas foram MD-INU: EXT (50:50) e EXT: Água (50:50), que foram secas por aspersão, para maior viabilidade, maior molhabilidade e solubilidade, baixa higroscopicidade e morfologia adequada para este tipo de produtos. A formulação foi composta por maltodextrina, inulina e extrato de café, e MD-INU: EXT (50:50) apresentou as melhores características físico-químicas e de viabilidade. O potencial do extrato de café foi comprovado como um material de parede em produtos probióticos microacapsulados, não lácteos, altamente ácidos. A viabilidade ótima foi alcançada, na ordem de $1 \times 10^{6} \mathrm{UFC} / \mathrm{mL}$, para ambas as formulações selecionadas, que mantiveram o potencial funcional por até 11 semanas de armazenamento.
\end{abstract}

Termos do índice: Probiótico, prebiótico, café, microencapsulação, extrato.

\section{INTRODUCTION}

Many individuals have decided to opt for healthy lifestyles, and functional food consumption has marked a tendency in the consumption said items and foods (VOS et al., 2010). The market for foods that are fiber-rich, provide vitamins, minerals with synergistic effects, and beneficial microorganisms for the prevention of chronic illness has been among the most important contributions to food development and innovation (BURGAIN et al., 2011). Similarly, there has been technological advancement for adaptation to functional food production, specifically with the addition of microcapsules that house bioactive components and probiotic microorganisms (MARTÍN et al., 2015; YE; GEORGES; SELOMULYA, 2018). Numerous investigations have indicated the benefits of frequent consumption of foods with probiotic activity (DE ARAUJOURIBE et al., 2018; DAS et al., 2013; RATHORE et al., 2013), as they confer a variety of health benefits on the consumer with frequent ingestion thereof. Functional products must present adequate sensorial and functional characteristics, as well as chemical, sensorial, and microbiological stability during processing and storage, in addition to guaranteeing compliance with safety standards. The existing gap in probiotic food generation is their incorporation into non-dairy products (baked products, meat products, fruit and legumebased products, mayonnaise and chocolate-based products), an alternative which would decrease the risks associated with lactose intolerance, allergies produced by lactic protein, and the consumption of saturated fat and cholesterol, among others (DE PRISCO; MAURIELLO, 2016; ROUF; JAN; SHARMA, 2018). In this case, microencapsulation permits their addition to a broad range of foods, which lends protection from adverse processing and storage factors (YE et al., 2018).

\footnotetext{
1,2Universidad de Caldas - Postal code 275 - Colombia - angela.ormaza@ucaldas.edu.co, felix.diaz@ucaldas.edu.co ${ }^{3}$ Faculty of Engineering and Architecture - Universidad Nacional de Colombia - Manizales branch. Postal code 127 - Colombia snrodriguezba@unal.edu.co
} 
Spray drying is among the most oftenused technologies in the microencapsulation of bioactive compounds (SOLANKI et al., 2013). Considering the thermic properties, among other characteristics of said materials, compounds with physicochemical and structural properties that preserve the functional qualities of encapsulated materials may be obtained. Low costs, short processing times, and the large number of potential wall materials present many advantages for bioactive compound protection (RODRÍGUEZRESTREPO; GIRALDO; RODRÍGUEZBARONA, 2017; SOLANKI et al., 2013).

Coffee is one of the most commonly consumed beverages in the world, but coffeebased product designs with functional qualities, and which provide probiotic microorganism benefits to the body have been little explored (DE PRISCO; MAURIELLO, 2016; ROUF et al., 2018). It should be noted that the $\mathrm{pH}$ of coffee does not affect the viability and stability of probiotic microorganisms, owing to their acid-tolerant nature (JURADO-GÁMEZ; CALPA-YAMÁ; CHASPUENGAL-TULCÁN, 2014).

Coffee represents an agricultural chain of significant economic impact in countries such as Brazil, Vietnam, the Ivory Coast, and Colombia, among others (LIANG et al., 2016). It may be worthwhile to explore formulation alternatives, which would confer functional qualities to this traditional, high-consumption beverage, so as to align said market with existing trends, toward the acquisition of bioactive foods that create positive, preventive impacts on human health (CARDONA et al., 2013; ZAPATA; CORTÉS; ROJANO, 2013; DÍAZ; ORMAZA; ROJANO, 2018).

Coffee extract possesses ideal physicochemical characteristics, which include low $\mathrm{pH}$ levels, antioxidant metabolite content, including polyphenols, tannins, and chlorogenic acid (DÍAZ et al., 2018), in addition to chemical compounds with significant sensorial value, including caffeine and an elevated number of volatile components with positive effects on coffee cup profiles (CHENG et al., 2016).

The objective in the present study is to evaluate coffee extract as a wall material for the encapsulation of L. casei ATCC 393, in combination with prebiotic carbohydrates, for the generation of a coffee-based, non-dairy functional beverage.

\section{MATERIALS AND METHODS}

\section{Raw materials}

\section{The probiotic microorganism}

The Lactobacillus casei ATCC 393 strain was acquired at a trading house, and was reactivated and conserved in cryovials at $-14{ }^{\circ} \mathrm{C} \pm 0.3$. It was cultivated in MRS (DE MAN ROGOSA; SHARP, 1969) and incubated at $37{ }^{\circ} \mathrm{C} \pm 0.2$. Biomass was obtained via microaerophilic fermentation in MRS (Scharlau, S.L, Spain) and recuperated via centrifugation (5,000 r.p.m.), and later washed in $0.85 \%$ saline solution. Fermentation was performed in triplicate. Colony-forming Unit $(\mathrm{CFU} / \mathrm{g})$ recounts, during tests, were performed by way of successive dilutions in peptone water, and planting in MRS agar.

\section{Excelso coffee}

Exactly $1,700 \mathrm{~g} \pm 0.6$ of excelso parchment coffee, of the Castillo variety, which originated in the municipality of Anserma, in the Caldas department (1,750 meters above sea level / 20 ${ }^{\circ} \mathrm{C} \pm 0.4 / 72 \% \pm 1.0$ relative humidity) were processed. The coffee was threshed (Quantik, CR2000, Armenia, Colombia) and defective beans and pasilla coffee were eliminated. The coffee retained on the 14/64" netting (U.G.Q. excelso coffee) was preserved, and later, the classified coffee was roasted, at $190{ }^{\circ} \mathrm{C} \pm 0.2$, and set at $100 \%$ power (Quantik, TC-150 A/R, Armenia, Colombia). Finally, the roasted coffee was milled to a medium grind (Grindmaster 810, México).

\section{Wall materials}

Coffee extract (EXT) was acquired from Descafecol S.A.S. (Manizales, Caldas, Colombia). Powdered skim milk (SM) (Colanta brand, Manizales, Colombia), inulin (INU), and maltodextrin (MD) were acquired from the Tecnas S.A. trading house (Medellin, Colombia).

\section{Wall material formulations}

Five wall material formulations were evaluated, and their physicochemical characteristics were determined. Soluble solids did not exceed $25 \% \mathrm{w} / \mathrm{w}$ in any case. The formulations considered were as follows: SM:MDINU (50:50 p/p), SM:MD-INU:EXT (25:50:25), MD-INU:EXT (50:50), MD-INU (50:50), and EXT:Water (50:50). The L. casei microorganism was incorporated into each of the formulations, in an initial concentration of $10^{9} \mathrm{CFU} / \mathrm{mL}$. 


\section{The microencapsulation process}

The microcapsules with each $L$. casei formulation were obtained from a spray dryer, equipped with a rotary atomizer (PSALAB, Vibrasec S.A.S., Medellin, Colombia), with a $25.5 \mathrm{~g} /$ minute feeding velocity. Entry and exit air temperatures were $130{ }^{\circ} \mathrm{C} \pm 0.6$ and $80{ }^{\circ} \mathrm{C} \pm$ 0.7 , respectively. Speed was set at 35,000 r.p.m. (HOYOS-LEYVA et al., 2018). Microcapsules were recovered in sterile conditions and packed into medium barrier metallized bags and stored at room temperature $\left(20{ }^{\circ} \mathrm{C} \pm 0.5\right.$ and $73 \% \pm 1.1$ relative humidity) until used.

\section{Physicochemical characterization of wall materials and microcapsules}

Soluble solids were determined in the wall material formulation suspensions via refractometer (Atago, RX-7000 $\alpha$, USA), equipped with a controlled thermostat (Peltier module) at $20{ }^{\circ} \mathrm{C} \pm 0.3$. The $\mathrm{pH}$ reading was obtained with Mettler-Toledo, S20 SevenEasy ${ }^{\mathrm{TM}}$ equipment from Switzerland. The determination of titratable acidity was performed by way of potentiometry ( $\mathrm{pH}=6.5$ equivalence point) with a standard sodium hydroxide solution $(0.1 \mathrm{~mol} / \mathrm{L})$ (NTC 5247, 2004). Microcapsule moisture content was determined with a drying stove (Binder, E28, Germany), set at $70^{\circ} \mathrm{C} \pm 0.5$, for 24 hours, and with a digital balance with $0.0001 \mathrm{~g}$ precision (MettlerToledo, AE100, Switzerland). Water activity $\left(\mathrm{a}_{\mathrm{w}}\right)$ was measured with a hygrometer with a $25^{\circ} \mathrm{C} \pm$ 0.5 dew point (Decagon, AquaLab, CX-1, USA).

Additionally, the following analyses were considered:

\section{Hygroscopicity}

Exactly $1 \mathrm{~g} \pm 0.3$ of microencapsulate material was placed on a fine-pore, stainless steel netting, in sterile conditions, with a saturated $\mathrm{NaCl}$ solution to achieve a relative humidity, within the recipient, of $75.3 \% \pm 0.7$, at $25{ }^{\circ} \mathrm{C}$ \pm 0.2 . The sample and saturated solution were stored for one week, and after this time, samples were weighed. Hygroscopicity was expressed as grams of absorbed moisture per $100 \mathrm{~g}$ of dry solids (FRITZEN-FREIRE et al., 2012).

\section{Solubility}

Exactly $1 \quad \mathrm{~g} \quad \pm \quad 0.3$ samples of microencapsulated material were dissolved into $100 \mathrm{~mL} \pm 0.2$ of distilled water, in accordance with the procedure, as modified by Rodríguez-
Restrepo et al., (2017). The solution was placed on a C-MAG H57 heating plate (IKA Labortechnik, Staufen, Germany) at $30{ }^{\circ} \mathrm{C} \pm 2$, stirring at 120 r.p.m., for five minutes. The suspension was centrifuged (Indulab, 04 Special, Colombia) at 3,000 r.p.m. for five minutes. An aliquot of $25 \mathrm{~mL}$ \pm 0.2 of supernatant liquid was taken and placed in a previously-weighed Petri dish. The sample dried (Binder, E28, Germany) at $105^{\circ} \mathrm{C} \pm 0.3$, for five hours, until it achieved a consistent weight. Recuperated solids were weighed after drying $(m)$, and the solubility percentage with weight difference was calculated via Equation 1. The $m_{i}$ parameter is equivalent to $0.25 \mathrm{~g}$.

$\%$ Solubility $=\left(\frac{m_{i}-m_{f}}{m_{i}}\right) X 100$

\section{Wettability}

For this determination, a cuboid stationary wetting device was employed for the procedure, as modified by Ceballos, Giraldo, and Orrego (2012). Wetting time was expressed in minutes, and was equivalent to the time that the complete immersion of one gram of microencapsulated material, deposited carefully into $100 \mathrm{~mL} \pm 0.4$ of water, at a temperature of $20^{\circ} \mathrm{C} \pm 0.2$, would take.

\section{Morphology of microencapsulated material}

The structure and morphology of the microencapsulated material was observed with an environmental scanning electron microscope, ESEM (Environmental Scanning Electron Microscope, Philips, XL30, USA), with an acceleration voltage of between 25 and $30 \mathrm{kV}$, and a pressure of 0.8 Torr (RODRÍGUEZ-BARONA; MONTES; RAMÍREZ, 2012). Micrographies were taken of the selected two best formulations.

\section{Viability}

The L. casei viability percentage was periodically determined via a recount of colonyforming units $(\mathrm{CFU} / \mathrm{mL})$ in microencapsulated samples, and was calculated via Equation 2 (FRITZEN-FREIRE et al., 2012). $\log N$ and $\log N_{0}$ are the number of viable and inoculated encapsulated cells, respectively.

$\%$ Viability $=\frac{\log N}{\log N_{0}} \times 100$ 
Wall material selection criteria considered those physicochemical qualities which are favorable for powdered ingredient and microorganism viability, both before and after microencapsulation.

\section{Sensorial evaluation of microcapsule mixes with $L$. casei and roasted, ground coffee}

The two best wall material mixtures of material microencapsulated at 10 and $20 \%$, with roasted, U.G.Q. ground coffee, were selected. Microcapsules with $L$. casei were evaluated in hot water, as a soluble coffee-based beverage ( $7 \mathrm{~g} \pm$ 0.1 of coffee / $150 \mathrm{~mL} \pm 0.5$ of hot water). Each of the mixtures was evaluated via the cup profile, and their sensorial attributes were compared to U.G.Q. coffee (DÍAZ et al., 2018). For this, the Q.D.A. (Quantitative Descriptive Analysis) profile test was applied, with one rating per taster (three expert tasters participated). The attributes evaluated were as follows: fragrance, aroma, acidity, bitterness, body, residual flavor, and overall impression, for each mixture (NTC 3566, 2011). Average ratings for each attribute were represented as radial graphs.

\section{Stability in storage}

The stability of the microencapsulated material was evaluated with the percentage of roasted, ground coffee, during a 12-week time span, at room temperature $\left(20{ }^{\circ} \mathrm{C} \pm 0.3\right.$ and 72 $\% \pm 1.2$ relative humidity), packed in airtight, metalized bags with a medium barrier. The stability parameters studied were: viability percentage (Equation 2) and the viable $L$. casei cell recount (CFU/mL) for the two best formulations selected.

\section{Statistical analyses}

All tests were performed in triplicate, and results were represented as the (average \pm deviation) standard of said replicas. The data were analyzed with variance analysis (ANOVA), and statistical significance was set at $p<0.05$. The $R$ Development Core Team software was employed, and an experimental design of a factor with repeated measurements was applied.

\section{RESULTS AND DISCUSSION}

\section{Physicochemical properties of wall material and microcapsules}

Table 1 presents the physicochemical properties determined for the wall materials and five formulations evaluated from these mixtures. The soluble solid percentage, measured in degrees Brix, was between 17 and 25. This parameter is important because it may influence the microencapsulation process' performance, and as the powder obtained will be used for the preparation of a coffee-based beverage, said soluble solid percentage may influence the body and flavor of the beverage obtained. The $\mathrm{pH}$ of the suspensions evaluated was in the $4.8-6.5$ range. The optimal $\mathrm{pH}$ for $L$. casei development is between 6.0 and 7.0. However, because of its lactic acid content, it is an acid-tolerant microorganism (JURADO-GÁMEZ et al., 2014), thus, the mixtures obtained may not cause adverse effects, from the cell-viability perspective. Mixtures with extract presented much higher acidities, in the 9.4 - 10.7 range. It is probable that hydroxycinnamic acid content, including chlorogenic acid, which is found in higher concentrations in the arabica variety, influenced the mixture's acidity (CHENG et al., 2016). Additionally, caffeine, trigonelline, and carboxylic acids such as citric, acetic, and formic acid, may favor acidification (DE LUCA et al., 2016). However, it was observed that mixtures with skim milk in their composition presented low acidity levels, in the 1.0-2.0 range, as skim milk may have a buffering effect. The ANOVA indicated significant differences $(p<0.05)$ between the formulations evaluated and the physicochemical parameters described in Table 1.

Certain properties of the obtained capsules may favor their applicability in powder matrices. Hygroscopicity parameters and solubility are key to stability during product storage. Hygroscopicity and moisture affect structural aspects and material composition, which is reflected in its ability to absorb water from the environment (SOUKOULIS et al., 2014).

Table 2 shows the moisture content, water activity, hygroscopicity, solubility, and wettability of the powders obtained, as related to their interaction with water and possible effect on capsule stability in a powder matrix. Moisture content varied from 2.5-3.1\%. These values show that the material obtained had high dry material content, and the reported water activity values $(0.22$ and 0.32$)$ indicate that high material stability may be predicted, under adequate storage conditions (NUÑEZ-MANCILLA et al., 2013). The water activity values shown in Table 2 coincide with those reported by Hoyos-Leyva et al. (2017), for taro starch microcapsules with L-ascorbic acid, obtained by spray drying. 
TABLE 1 - Chemical characterization of wall material formulations evaluated for L. casei microencapsulation, obtained by spray drying.

\begin{tabular}{cccc}
\hline Formulation type & ${ }^{\circ}$ Brix & pH & Acidity $(\mathbf{m L}$ NaOH/g) \\
\hline SM:MD-INU (50:50) & $24.4 \pm 0.55 \mathrm{a}$ & $6.5 \pm 0.02 \mathrm{a}$ & $1.4 \pm 0.13 \mathrm{a}$ \\
\hline SM:MD-INU:EXT (25:50:25) & $20.8 \pm 0.06 \mathrm{~b}$ & $6.0 \pm 0.01 \mathrm{~b}$ & $2.2 \pm 0.19 \mathrm{~b}$ \\
\hline MD-INU:EXT (50:50) & $17.7 \pm 0.06 \mathrm{c}$ & $5.8 \pm 0.03 \mathrm{c}$ & $10.7 \pm 0.58 \mathrm{c}$ \\
\hline MD-INU (50:50) & $24.1 \pm 0.17 \mathrm{a}$ & $5.8 \pm 0.08 \mathrm{c}$ & $3.1 \pm 0.08 \mathrm{~d}$ \\
\hline EXT-Water (50:50) & $25.6 \pm 0.11 \mathrm{~d}$ & $4.8 \pm 0.05 \mathrm{~d}$ & $9.4 \pm 0.14 \mathrm{e}$ \\
\hline Extract (EXT) & $52.2 \pm 0.12 \mathrm{e}$ & $4.8 \pm 0.04 \mathrm{~d}$ & $9.8 \pm 0.16 \mathrm{e}$ \\
\hline
\end{tabular}

Average values $(n=3)$ with different letters $(a-b-c-d-e)$ in the same row indicate statistical differences at the $5 \%$ significance level $(\mathrm{p}<0.05)$.

SM: Skim Milk, MD: Maltodextrin, INU: Inulin, EXT: Coffee Extract

TABLE 2 - Physicochemical characterization of microcapsules with L. casei obtained by spray drying.

\begin{tabular}{|c|c|c|c|c|c|}
\hline Formulation type & H (\%) & $a_{w}$ & $\begin{array}{c}\text { Hygroscopicity } \\
\text { (g } \mathrm{H}_{2} \mathrm{O} / 100 \mathrm{~g} \text { d. s.) }\end{array}$ & $\begin{array}{c}\text { Solubility } \\
(\%)\end{array}$ & Wettability (s) \\
\hline SM:MD-INU (50:50) & $2.51 \pm 0.2 \mathrm{a}$ & $0.22 \pm 0.4 \mathrm{a}$ & $6.9 \pm 0.4 \mathrm{a}$ & $99.5 \pm 0.2 \mathrm{a}$ & $11.5 \pm 0.4 \mathrm{a}$ \\
\hline $\begin{array}{c}\text { SM:MD- } \\
\text { INU:EXT(25:50:25) }\end{array}$ & $2.73 \pm 0.6 \mathrm{~b}$ & $0.28 \pm 0.6 \mathrm{~b}$ & $11.4 \pm 0.7 \mathrm{~b}$ & $97.9 \pm 0.6 \mathrm{~b}$ & $8.3 \pm 0.5 \mathrm{~b}$ \\
\hline $\begin{array}{c}\text { MD-INU:EXT } \\
(50: 50)\end{array}$ & $2.89 \pm 0.4 \mathrm{~b}$ & $0.30 \pm 0.8 \mathrm{c}$ & $16.0 \pm 0.9 \mathrm{c}$ & $99.2 \pm 0.2 \mathrm{a}$ & $8.9 \pm 0.5 \mathrm{~b}$ \\
\hline MD-INU (50:50) & $2.68 \pm 0.1 \mathrm{a}$ & $0.25 \pm 0.2 \mathrm{~b}$ & $8.0 \pm 0.5 \mathrm{~d}$ & $95.6 \pm 0.9 \mathrm{c}$ & $9.7 \pm 0.5 \mathrm{c}$ \\
\hline EXT-Water $(50: 50)$ & $3.13 \pm 0.8 \mathrm{c}$ & $0.32 \pm 0.3 \mathrm{c}$ & $21.16 \pm 0.01 \mathrm{e}$ & $99.7 \pm 0.4 \mathrm{a}$ & $8.1 \pm 0.4 \mathrm{~b}$ \\
\hline
\end{tabular}

Likewise, the water activity and humidity content values reported by Rocha et al. (2019) for microcapsules made of protein concentrated from serum, maltodextrin, and acacia gum that contains phenolic extracts by way of spray drying matched those indicated in the present study.

Average values $(n=3)$ with different letters $(\mathrm{a}-\mathrm{b}-\mathrm{c}-\mathrm{d}-\mathrm{e})$ in the same row indicate statistical differences at the $5 \%$ significance level $(\mathrm{p}<0.05)$. db: dry base.

SM: Skim milk, MD: Maltodextrin, INU: Inulin, EXT: Coffee Extract HC: Humidity Content, $\mathrm{a}_{\mathrm{w}}$ : Water activity

In relation to the hygroscopicity values obtained, it may be said that formulations with less environmental moisture capture were those suspensions composed thus: SM:MD-INU (50:50) and MD-INU (50:50), in the order of 6.9 and $8.0 \mathrm{~g} \mathrm{H}_{2} \mathrm{O} / 100 \mathrm{~g}$ d.s., respectively. The remaining formulations presented higher values, where the EXT-Water (50:50) and MD-INU:EXT (50:50) formulations presented higher values, corresponding to 21.16 and $16.0 \mathrm{~g} \mathrm{H}_{2} \mathrm{O} / 100 \mathrm{~g}$ d.s., respectively. Hygroscopicity may be related to structural and composition aspects of the matrix, and also, be due to storage conditions, including temperature and relative humidity. In this case, an increase in water content would cause plastification and changes to a rubbery state, as a result of the diffusion of vapor through the solid-air interface (SOUKOULIS; BEHBOUDI-JOBBEHDAR, 2014). A powder with low hygroscopicity and water content, low degree of caking, and high solubility is considered a good powder, in terms of stability (BHUSARI et al., 2014). Evidently, the incorporation of solutes contributes to the reduction of hygroscopicity in samples (SOUKOULIS; BEHBOUDI-JOBBEHDAR, 2014). Sun, Cameron and Bai (2019), indicated that carvacrol microcapsules in a pectin-alginate matrix, obtained by spray drying, presented an average hygroscopicity value of $34.44 \mathrm{~g} \mathrm{H}_{2} \mathrm{O} / 100$ $\mathrm{g}$, which is slightly above those reported in the six formulations evaluated in the present study. In accordance with Rodríguez-Restrepo et al. (2017), the hygroscopicity achieved in microcapsules 
composed of isolated soy protein, acacia gum, and powdered whole milk, with the application of spray drying was in the range of 4.45 to 15.21 $\mathrm{g} \mathrm{H}_{2} \mathrm{O} / 100 \mathrm{~g}$, which presented values near those reported herein (Table 2).

In terms of solubility, all analyzed mixtures indicated values for this parameter which were greater than $95 \%$. Said values are within the solubility range for foods or powdered food ingredients between 67.05 and $99.98 \%$ (JAYA; DAS, 2004). Rocha et al. (2019), indicated that the microencapsulation of phenolic extracts, within a wall conformed of protein concentrated from serum, maltodextrin, and acacia gum, by way of atomization, generated a powdered material with solubilities which varied between 41.33 and 90.27 $\%$. Said values are far below those indicated in Table 2.

Wall material formulations with the lowest wettability were SM:MD-INU (50:50) and MDINU (50:50), in the order of 11.5 and $9.7 \mathrm{~s}$, respectively, while other suspensions presented greater rehydration or reconstitution capacity. Wettability depends heavily upon material composition, especially content of sugar or other hydrophilic solutes (ABDALLA; MOHAMMED; MUDAWI, 2010). Carvacrol microencapsulation in a pectin-alginate matrix exhibited wettability of $4.55 \mathrm{~min}$ (SUN et al., 2019). The protein from concentrated serum, maltodextrin, and acacia gum microcapsule formation, to encapsulate phenolic extracts by way of the atomization process presented wettability values in the order of 74.5 to $319.5 \mathrm{~s}$ (ROCHA et al., 2019). Both studies presented elevated values for this response variable, as compared to those reported herein (below $15 \mathrm{~s}$ ). Reports were not found in which coffee extract was used as encapsulant material, which would have permitted a more proximate comparison. The ANOVA indicated statistically significant differences $(p<0.05)$ between the formulations evaluated and the physicochemical parameters studied in Table 2. When the microencapsulated material presents low hygroscopicity, low moisture content, and high solubility, it is considered a powdered food of high quality, as its characteristics favor stability (BHUSARI; MUZAFFAR; KUMAR, 2014).

The viability percentage and recount of viable cells following $L$. casei spray drying was greatest for the suspensions made with MDINU:EXT (50:50) and EXT-Water (50:50) (Table 3). Similarly, the cell recount established a range between $10^{7}$ and $10^{10} \mathrm{CFU} / \mathrm{g}$ for all wall material formulations evaluated. In accordance to the norm for probiotic foods, the concentration of viable cells in the product must not be below $10^{6} \mathrm{CFU} / \mathrm{mL}$ or grams. Some researchers have reported viability values for encapsulated microorganisms with the spray drying technique, within the range obtained (Table 3). These include Lactobacillus paracasei (CASSANEGO et al., 2015), Lactobacillus acidophilus (YONECURA et al., 2014), and a probiotic triad of Bacillus Polymyxa, Bacillus Megaterium, and Lactobacillus Delbruekii subsp. Bulgaricus (DE ARAUJO-URIBE et al, 2018).

\section{Selection of wall material formulations for $L$. casei encapsulation by way of spray drying for use as an ingredient in a coffee beverage}

In accordance to the physicochemical characteristics evaluated and the viability percentage obtained following encapsulation, the formulations selected to be mixed with roasted, ground excelso-quality coffee were: MD-INU:EXT (50:50) and EXT-Water (50:50). This was due to their composition and look with roasted, ground coffee, including the color, smell, and flavor of the beverage, owing to their coffee extract content. It should be mentioned that the formulations that did not contain coffee extract were white, and so mixing these with the roasted, ground coffee created a brightening effect, as compared to conventional coffee-based beverages, especially owing to the presence of maltodextrin (CAPARINO et al., 2012). Additionally, its presence prevents problems of material stickiness within the spray dryer, as an effect of its high glass transition temperature (CAPARINO et al., 2012).

\section{Morphology of obtained microcapsules}

The micrographies observed, via ESEM, of the capsules obtained with the selected materials are shown in Figure 1. The microcapsules obtained following spray drying of the MD-INU:EXT (50:50) (Figure 2A) mixture presented spherical form and greater size than those obtained with the EXT-Water (50:50) mixture (Figure 2B).

It was observed that the coffee extract presented an adequate combination with carbonate the MD and INU hydrate-type prebiotics employed. The presence of extracellular material was not determined, with the exception of spherical microcapsules, which permits the consideration of an adequate wall mixture composition, as the encapsulate was contained within both polymeric walls (KIM et al., 2008). 
TABLE 3 - Viability and recount of $L$. casei cells obtained by spray drying.

\begin{tabular}{ccc}
\hline Formulation type with $\boldsymbol{L}$. casei & $\begin{array}{c}\text { Viability } \\
\text { (\%) }\end{array}$ & $\begin{array}{c}\text { Viable } \boldsymbol{L} \text {. casei cell recount } \\
\text { (CFU/g) }\end{array}$ \\
\hline SM:MD-INU (50:50) & $93.4 \pm 0.1 \mathrm{a}$ & $9.6 \times 10^{9} \mathrm{a}$ \\
\hline SM:MD-INU:EXT (25:50:25) & $98.7 \pm 0.5 \mathrm{~b}$ & $1.1 \times 10^{10} \mathrm{~b}$ \\
\hline MD-INU:EXT (50:50) & $99.1 \pm 0.7 \mathrm{c}$ & $5.9 \times 10^{8} \mathrm{c}$ \\
\hline MD-INU (50:50) & $93.7 \pm 0.8 \mathrm{a}$ & $1.0 \times 10^{7} \mathrm{~d}$ \\
\hline EXT-Water (50:50) & $99.7 \pm 0.3 \mathrm{c}$ & $4.3 \times 10^{10} \mathrm{~b}$
\end{tabular}

Average values $(n=3)$ with different letters $(a-b-c-d-e)$ in the same row indicate statistical differences at the $5 \%$ significance level $(\mathrm{p}<0.05)$.

SM: Skim milk, MD: Maltodextrin, INU: Inulin, EXT: Coffee Extract

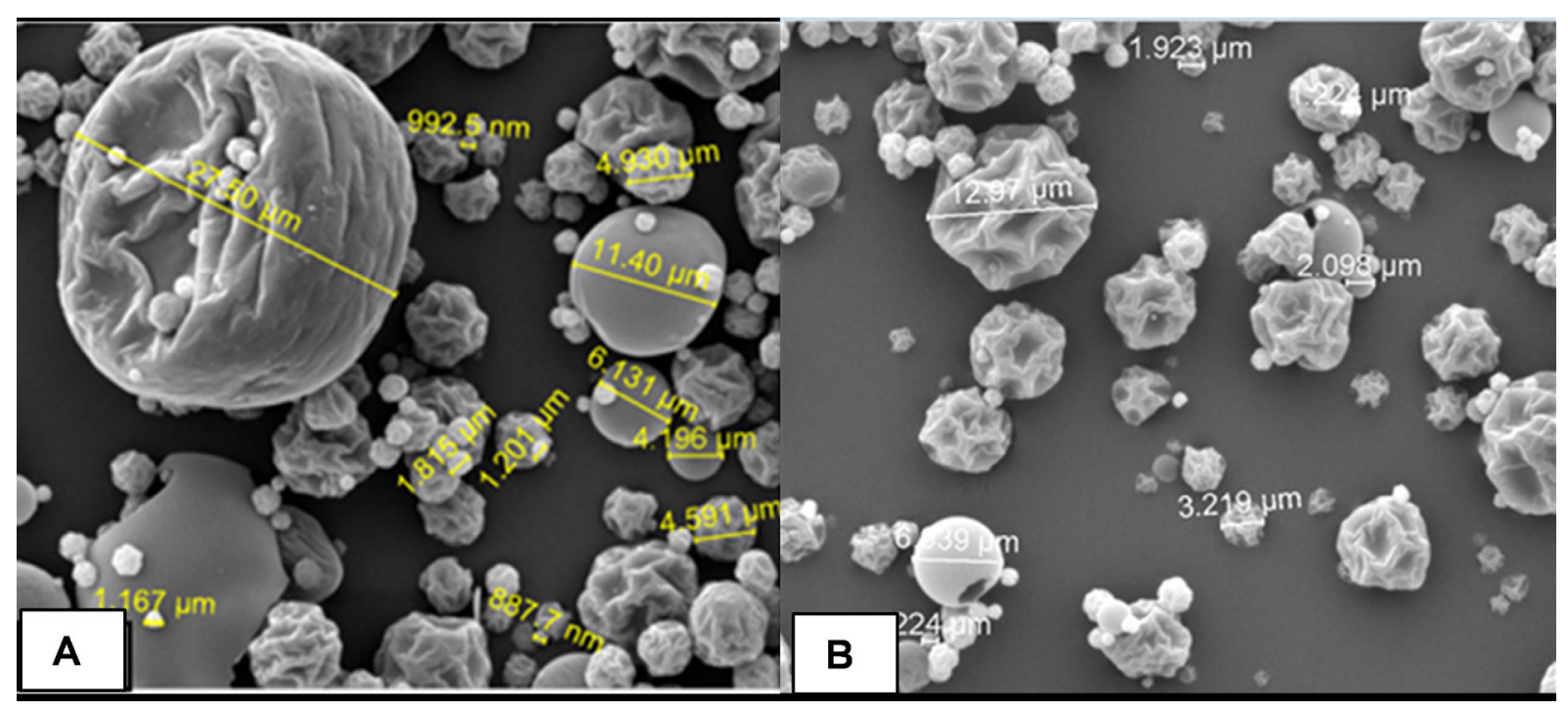

FIGURE 1 - ESEM Micrographs. Dried by aspersion 5000X. Microcapsules with wall material composed of A: MD-INU:EXT (50:50) y B: EXT-Water (50:50).

The presence of inulin and maltodextrin may promote the formation of a greater wall material interconnection, which contributes to improved cell protection and liberation control (GUEDES et al., 2018). Additionally, it was observed that those microcapsules obtained with the EXT-Water (50:50) mixture presented, on average, smaller size $(6.36 \pm 4.92 \mu \mathrm{m})$ and a rougher surfaces, likely owing to lower sugar content, as this facilitates the formation of a smooth, interconnected film. For the MD-INU:EXT (50:50) formulation, the capsules obtained were, on average, of greater size $(7.33 \mu \mathrm{m} \pm 4.37)$, and on average presented larger particulate size than samples without prebiotic carbohydrates, had generally smoother surfaces, and the morphology presented corresponded to that of dehydrated structures. Generally, both treatments presented adequate sizes to house the microorganism, 0.25 micras and larger (JURADOGÁMEZ; GÚZMAN-INSUASTY, 2015).
In relation to the formulations that contain coffee extract, it was generally observed that said material exhibits good wall-formation properties, as related to hygroscopicity, wettability, solubility, and morphological characteristics, which may be related to its high water-soluble polysaccharide concentration and functional properties (RODRÍGUEZ-RESTREPO et al., 2017;SEQUERA et al., 2019). Its potential as encapsulant material in probiotic food is derived from the aforementioned aspects.

\section{Incorporation of microencapsulates with roasted and ground coffee}

Considering the recount of viable $L$. casei cells in the microencapsulated powder, the incorporation percentage of product for the mixture with roasted, ground coffee was evaluated at 10 
and $20 \%$, with the chosen formulations: EXTWater and MD-INU:EXT (50:50), respectively.

On sensorial evaluation (Figure 2), the microencapsulate mixture of $L$. casei with EXT-Water wall material (50:50), at $10 \%$ roasted, ground coffee, yielded a beverage with pronounced bitter flavor and slight spicy notes that are uncharacteristic of the beverage, were obtained, as an effect of the coffee extract. The same formulation, but with a $20 \%$ concentration yielded better flavor than the $10 \%$ concentration, as the acidic and bitter flavors were enhanced. Further, the overall impression increased slightly from that of the incorporation of microencapsulated material at $10 \%$. The coffee was perceived as one with added sweetener or a sugar substitute. It was noted that the increase in the mixture percentage increased acidity and bitterness in the resulting probiotic beverage.

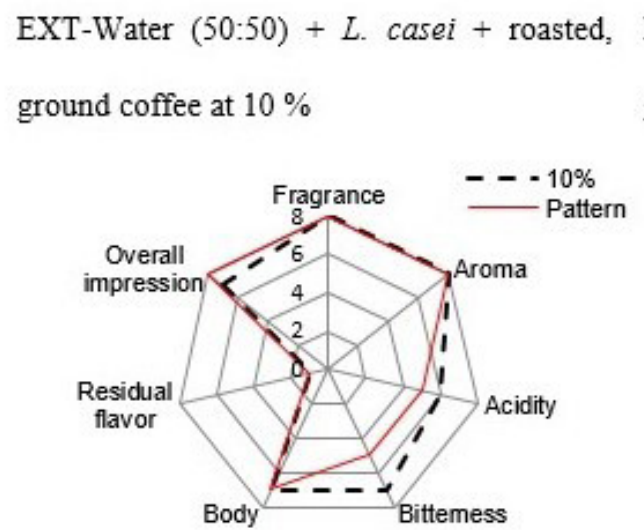

The beverage obtained with $10 \%$ material microencapsulated with $L$. casei, with the MDINU:EXT (50:50) mixture of wall material, presented marked bitterness notes and had a higher overall impression rating than the EXT:Water (50:50) mixture. Additionally, it presented an equal rating for the overall impression descriptor, for the beverage with $20 \%$ incorporation of microcapsules with L. casei EXT-Water (50:50).

The $20 \%$ L. casei mixture with MDINU:EXT (50:50) presented acidic notes identical to the excelso pattern, although the bitter flavor increased slightly. Comparing this percentage to the other treatments (with 10 and $20 \%$ incorporation of microcapsules with $L$. casei EXT-Water (50:50) and $10 \%$ microcapsules with $L$. casei MDINU:EXT (50:50)) the same overall impression, fragrance, aroma, and body of U.G.Q. coffee was achieved, and this presented the best acceptance rating of all probiotic beverages evaluated.

INU-MD:EXT $(50: 50)+L$. casei + roasted,

ground coffee at $10 \%$

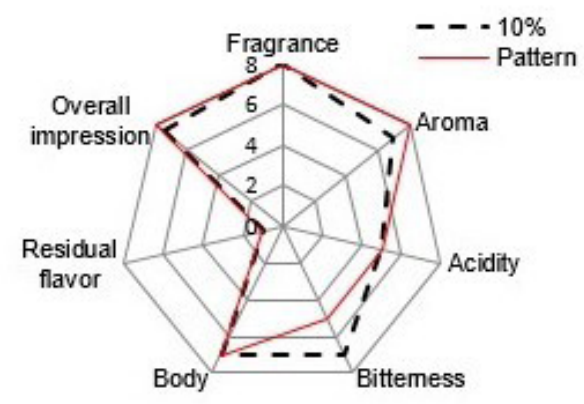

EXT-Water $(50: 50)+L$. casei + roasted, INU-MD:EXT $(50: 50)+L$. casei + roasted,

ground coffee at $20 \%$

ground coffee at $20 \%$
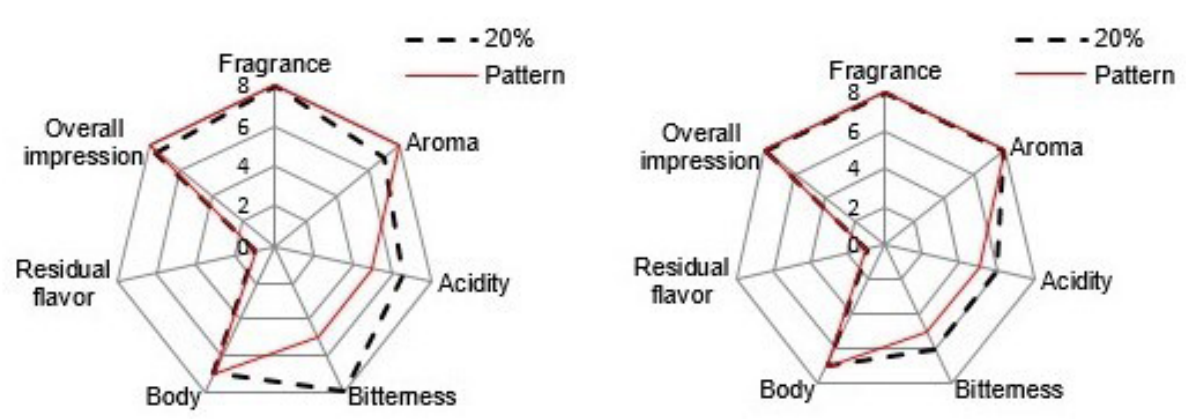

FIGURE 2 - Sensorial analysis of the mixtures at 10 and $20 \%$ of microcapsules with $L$. casei and roasted, ground coffee from the selected formulations, respectively. 
It may be noted that the incorporation of INU and MD drastically decreased acidity and maintained the bitter notes that are characteristic of this beverage (Cheng et al., 2016). The statistical analysis indicated a significant difference $(p<0.05)$ between the incorporation percentage of microencapsulated material and the roasted, ground coffee and cup profile of the evaluated beverages.

On choosing the $20 \%$ optimal incorporation percentage, $20 \%$ powdered microcapsules were mixed with hot water, and their sensorial profile was analyzed and compared to the excelso pattern, in order to observe whether these may be solubilized with hot water and present sensorial similarities to excelso coffee. This data is shown in Figure 3.

The microcapsules soluble in hot water, with the EXT-Water (50:50) formulation, presented little body and slightly bitter notes, compared to U.G.Q. excelso coffee. The color of the beverage obtained was lighter than the characteristic color of coffee-based beverages. Slightly spicy notes were perceived with this formulation. The minimal body may be explained by the presence of water, which has a diluting effect on beverages.

Microcapsules with $L$. casei and MDINU:EXT (50:50) in hot water presented little body and mildly-low acidity compared to the EXT-Water (50:50) microcapsules. The overall impression of this drink was identical to that of an excelso coffee. The color of the beverages was lighter than that of conventional coffee beverages. When these microcapsules were mixed with coffee, it was observed that the body of the probiotic beverage was improved by the roasted, ground coffee. The statistical analysis indicated a significant difference $(\mathrm{p}<0.05)$ between the percentage of incorporation of microencapsulated material and sample sensorial profiles.

\section{Stability of microcapsules with $L$. casei incorporated in $20 \%$ to roasted, ground coffee}

Figure 4 shows the evolution of the viability percentage of the encapsulated $L$. casei strain in the selected mixtures, MD-INU:EXT (50:50) and EXT-Water (50:50). After 12 weeks of storage, a pronounced drop in EXT-Water (50:50) encapsulate viability, mixed to $20 \%$ was observed, with a significant statistical difference in this parameter $(p<0.05)$. However, in MDINU:EXT (50:50) at $20 \%$ microcapsule storage, a slight drop was obtained with a very high viability percentage, compared to the EXT-Water (50:50) microcapsules. The statistical analysis did not indicate a significant difference $(\mathrm{p}>0.05)$ between the viability percentage and $20 \%$ MD-INU:EXT (50:50) storage time.

Figure 5 represents the viable cell recount of the selected formulations, mixed with a 20 $\%$ proportion of roasted, ground coffee, during 12 weeks of storage, and indicates significant differences $(\mathrm{p}<0.05)$ in the $L$. casei recount represented in $\mathrm{CFU} / \mathrm{mL}$. The recount remained above $1 \times 10^{6} \mathrm{CFU} / \mathrm{mL}$ until week 11 for both formulations, which indicates that it constitutes a probiotic food, in accordance with Colombian Ruling 333 (2011).
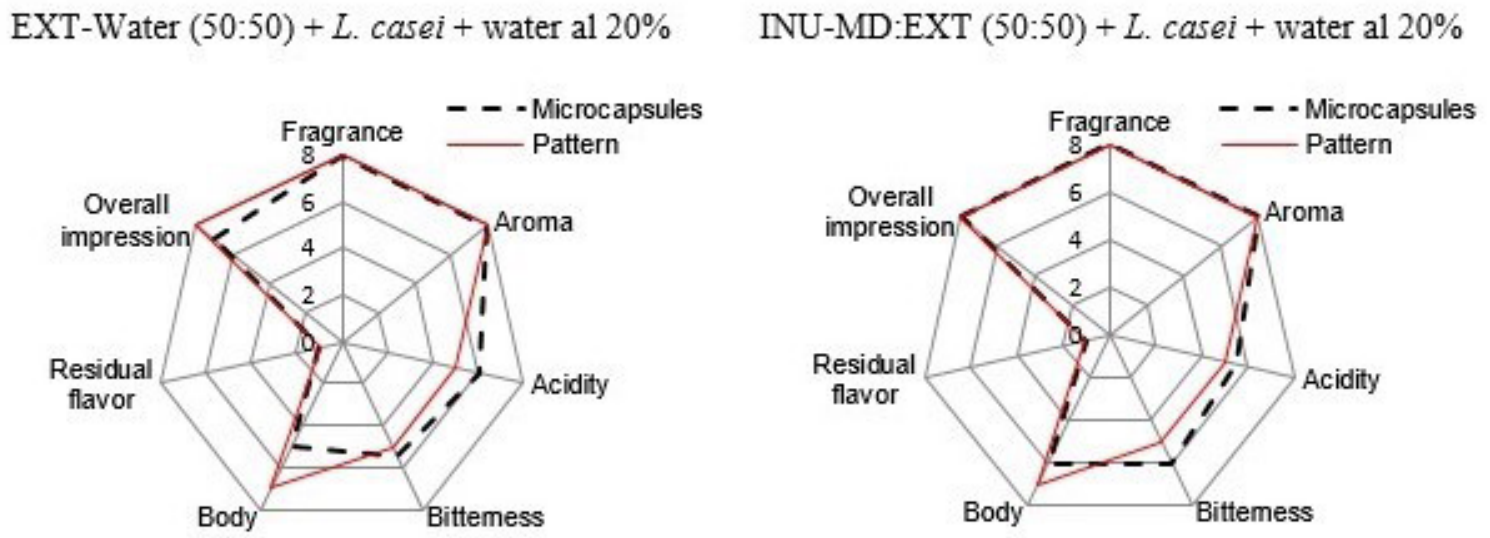

FIGURE 3 - Sensorial analysis of microcapsules with $L$. casei at $20 \%$ of MD-INU:EXT (50:50) and EXT-Water $(50: 50)$ in hot water, respectively. 
This parameter was indicated in Figure 5 as the lower limit.

Jurado-Gámez et al., (2014), indicated that L. casei, although it may survive at a $\mathrm{pH}$ near 5.0, may also develop adequately at $\mathrm{pH}$ values near 6.0 and 7.0, which match the MD-INU:EXT (50:50) and $L$. casei formulation, explaining the high viability percentage and cell recount for this formulation. Capela et al. (2006), found that the presence of oligosaccharides, as wall material in microencapsulation, was an important factor in probiotic survival during prolonged storage periods. Bearing a relationship with the results obtained in Figure 5, Burgain et al. (2011), indicated that, in the creation of cheddar cheese, with the addition of microencapsulated bifidobacteria, via spray drying, the microorganism was able to survive for seven weeks, and the $\mathrm{pH}$ of the cheese was maintained at an average value of 5.5. Additionally, another study evaluated bifidobacteria viability, over time, which had been encapsulated with calcium alginate for the formulation of probiotic mayonnaise. This indicated optimal microorganism viability up to week 10 (BURGAIN et al., 2011). However, the difference in the structure and composition of the matrices studied should be considered. In the case of coffee, parameters such as product humidity and $\mathrm{pH}$ could favor microcapsule stability.

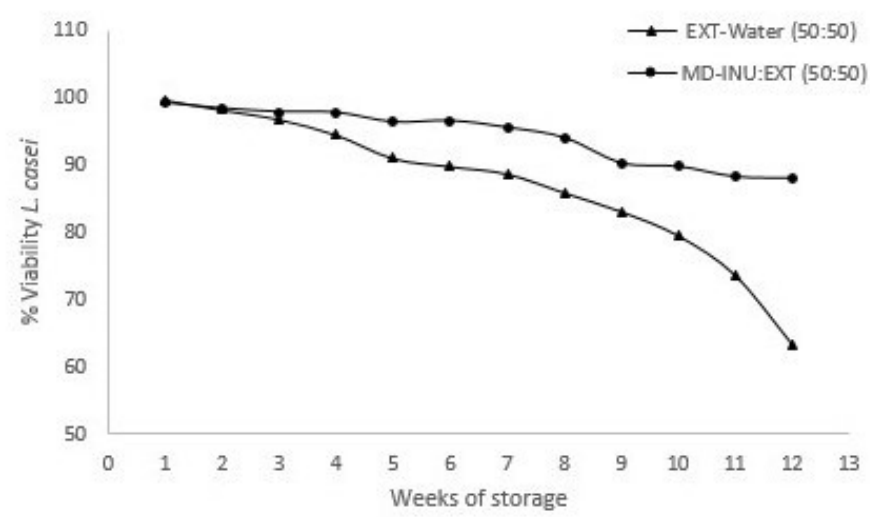

FIGURE 4 - Viability of microcapsules with $L$. casei stored with roasted, ground coffee at $20 \%$ for 12 weeks in the EXT-Water (50:50) and MD-INU:EXT (50:50) formulations, respectively.

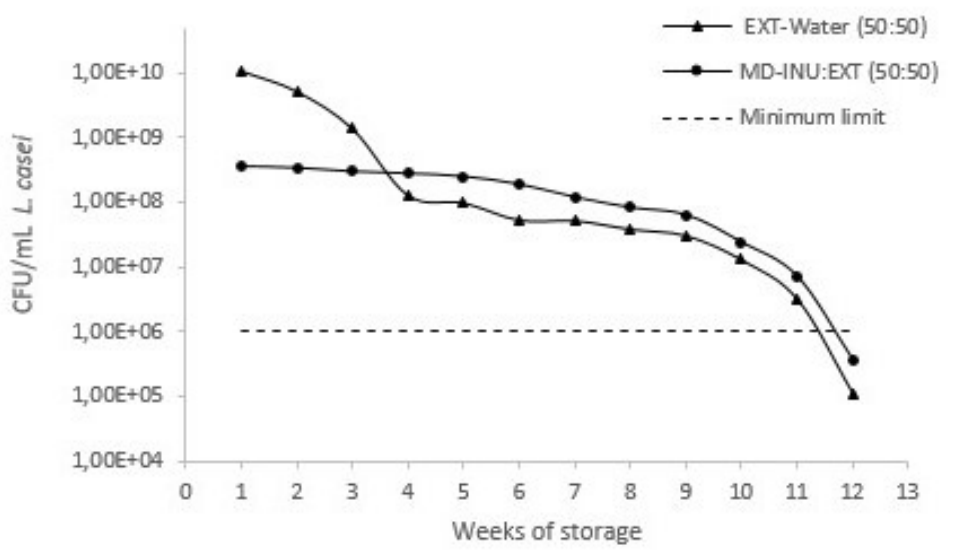

FIGURE 5 - Recount of viable $L$. casei cells contained in the stored microcapsules with roasted, ground coffee at $20 \%$ for 12 weeks in the EXT-Water (50:50) and MD-INU:EXT (50:50) formulations. 


\section{CONCLUSIONS}

The formulation selected for the coffeebased probiotic beverage was that composed of MD-INU:EXT (50:50) and L. casei, as it exhibited adequate viability (in excess of $1 \times 10^{6}$ $\mathrm{CFU} / \mathrm{mL}$ ) and physical and chemical properties, which shows the potential of coffee extract as encapsulant material. The optimal incorporation mixture of microcapsules with L. casei was 20 $\%$, with excelso coffee that had been roasted and ground. Medium-roast excelso coffee is ideal as a mixing material for microcapsules with $L$. casei ATCC 393, for beverage preparation, owing to its chemical and functional properties. Optimal viability was achieved in the order of de $1 \times 10^{6}$ $\mathrm{CFU} / \mathrm{mL}$, for up to 11 weeks in storage, without losing its probiotic food quality. A coffee-based probiotic beverage combines the health benefits of the probiotic strain and excelso coffee in a single food product. The product developed constitutes a contribution to the coffee agricultural chain, as it provides a beverage alternative with added value, a functional character, and sensorial qualities similar to those of a traditional coffee beverage.

\section{REFERENCES}

ABDALLA, A. A.; MOHAMMED, M. A.; MUDAWI H.A., Production and Quality of Instant Baobab (Adansonia digitata L.). Advance Journal of Food Science and Technology, Jartum, v. 2, n. 2, p. 125-133, 2010.

BHUSARI, S. N.; MUZAFFAR, K.; KUMAR, P. Effect of carrier agents on physical and microstructural properties of spray dried tamarind pulp powder. Powder Technology, Sangrūr, v. 266, p.354-364, 2014.

BURGAIN, J. C. et al. Encapsulation of probiotic living cells: From laboratory scale to industrial applications, Journal of Food Engineering, Nancy, v. 104, p. 467483, 2011.

CAPARINO, O.A. et al. Effect of drying methods on the physical properties and microstructures of mango (Philippine 'Carabao' var.) powder, Journal of Food Engineering, Pullman, v. 111, p. 135-148, 2012.

CAPELA, P.; HAY, T. K. C.; SHAH, N. P. Effect of cryoprotectants, prebiotics and microencapsulation on survival of probiotic organisms in yoghurt and freezedried yoghurt. Food Research International, Hong Kong, v. 39, p. 203-211, 2006.
CARDONA, F. et al. Benefits of polyphenols on gut microbiota and implications in human health. The Journal of Nutritional Biochemistry, Malaga, v. 24, n. 8, p. 1415-1422, 2013.

CASSANEGO, E. et al. Lactobacillus paracasei isolated from grape sourdough: acid, bile, salt, and heat tolerance after spray drying with skim milk and cheese whey. European Food Research and Technology, Florianopolis, v. 240, n. 5, p. 977- 984, 2015.

CEBALlOS, A. M.; GIRALDO, G. I.; ORREGO, C. E. Effect of freezing rate on quality parameters of freeze dried soursop fruit pulp. Journal of Food Engineering, Manizales, v. 111, p. 360-365, 2012.

CHENG, B. et al. Influence of genotype and environment on coffee quality. Trends in Food Science \& Technology, Santa Lucia, v. 57, p. 20-30, 2016.

DAS, J. K. et al. In vitro evaluation of anti-infective activity of a Lactobacillus plantarum strain against Salmonella enteric a serovar Enteritidis. Gut Pathogens, Texas, v. 5, n. 11, p. 1-11, 2013.

DE ARAUJO-URIBE, N. et al. Viability of probiotic bacteria Bacillus Polymyxa, Bacillus Megaterium and Lactobacillus Delbruekii subsp. bulgaricus microencapsulated under the spray-drying technique. DYNA, Medellín, v. 85, n. 204, p. 272-276, 2018.

DE LUCA, S. M. et al. Characterization of the effects of different roasting conditions on coffee samples of different geographical origins by HPLC-DAD, NIR and chemometrics. Microchemical Journal, Roma, v. 129, p. 348-361, 2016.

DE PRISCO, A.: MAURIELLO, G. Probiotication of foods: A focus on microencapsulation tool. Trends in Food Science \& Technology, Portici, v. 48, p. 27-39, 2016.

DÍAZ, F. O.; ORMAZA, A. M.; ROJANO, B. A. Efecto de la Tostión del Café (Coffea arabica L. var. Castillo) sobre el Perfil de Taza, Contenido de Compuestos Antioxidantes y la Actividad Antioxidante, Información Tecnológica, Manizales, v. 29, n. 4, p. 31-42, 2018.

FRITZEN-FREIRE, C. B. et al. Microencapsulation of bifidobacteria by spray drying in the presence of prebiotics. Food Research International, Florianopolis, v. 45, n. 1, p. 306-312, 2012. 
GUEDES SILVAA, K. C. et al. Symbiotic microencapsulation to enhance Lactobacillus acidophilus survival. LWT - Food Science and Technology, Campinas, v. 89, p. 503-509, 2018.

HOYOS-LEYVA, J. D. et al. Physical and chemical stability of L-ascorbic acid microencapsulated into taro starch spherical aggregates by spray drying. Food Hydrocolloids, Yautepec, v. 83, p. 143-152, 2018.

JURADO-GÁMEZ, H.; CALPA-YAMÁ, F.; CHASPUENGAL-TULCÁN, A. Determinación de parámetros cinéticos de Lactobacillus casei en dos medios probióticos. Veterinaria y Zootecnia, Pasto, v. 8, n. 2, p. 15-25, 2014.

JURADO-GÁMEZ, H.; GÚZMAN-INSUASTY, M. Determinación de la cinética, pruebas de crecimiento y efecto de inhibición in vitro de Lactobacillus casei en Staphylococcus aureus, Staphylococcus epidermidis, Streptococcus agalactiae y Escherichia coli. Revista de la Facultad de Medicina Veterinaria y de Zootecnia, Pasto, v. 62, n. 2, p. 23-39, 2015.

KIM, S. J. et al. Effect of microencapsulation on viability and other characteristics in Lactobacillus acidophilus ATCC 43121. LWT - Food Science and Technology, Seoul, v. 41, n. 3, p. 493-500, 2008.

LIANG, $\mathrm{N}$. et al. Interactions between major chlorogenic acid isomers and chemical changes in coffee brew that affect antioxidant activities. Food Chemistry, Vancouver, v. 213, p. 251-259, 2016.

MARTÍN, M. J. et al. Microencapsulation of bacteria: A review of different technologies and their impact on the probiotic effects. Innovative Food Science and Emerging Technologies, Granada, v. 27, p. 15-25, 2015.

NTC 3566:2011. Instituto Colombiano de Normas Técnicas y Certificación (Colombia), Café verde. Preparación de muestras para uso en análisis sensorial, p. 1-9, Bogotá, 2011.

NTC 5247: 2004. Instituto Colombiano de Normas técnicas y Certificación (Colombia), Café tostado en grano y/o molido. Determinación de la acidez titulable, p. 1-10, Bogotá, 2004.

NUÑEZ-MANCILLA, Y. et al. Osmotic dehydration under high hydrostatic pressure: Effects on antioxidant activity, total phenolics compounds, vitamin $\mathrm{C}$ and colour of strawberry (Fragaria vesca). LWT - Food Science and Technology, La Serena, v. 52, n. 2, p. 151156, 2013.
RATHORE, S. et al. Microencapsulation of microbial cells. Journal of Food Engineering, Singapore, v. 116, p. 369-381, 2013.

RESOLUCIÓN 333 de 2011: Ministerio de la Protección Social (Colombia), Reglamento técnico sobre los requisitos de rotulado o etiquetado nutricional que deben cumplir los alimentos envasados para consumo humano. Bogotá, 2011.

ROCHA, J.C.G. et al. Microencapsulation by atomization of the mixture of phenolic extracts. Powder Technology, Campinas, v. 343, p. 317-325, 2019.

RODRÍGUEZ-BARONA, S.; MONTES, L. M.; RAMIREZ, D. Microencapsulation of probiotic by spray drying in the presence of prebiotic. Vitae, Manizales, v. 19, n. 1, p. 185-188, 2012.

RODRÍGUEZ-RESTREPO, Y. A.; GIRALDO, G. I.; RODRÍGUEZ-BARONA, S. Solubility as a fundamental variable in the characterization of wall material by spray drying of food components: Application to microencapsulation of Bifidobacterium animalis subsp. Lactis. Journal of Food Process Engineering, Manizales, v. 40, p. 1-8, 2017.

ROUF, S. A.; JAN, T.; SHARMA, P. Non-Dairy Probiotics - An Emerging Trend in Health Care Products. International Journal of Current Microbiology and Applied Sciences, Shalimar, v. 7, n. 10, p. 131-145, 2018.

SEQUERA, S. C.; RUIZ, Y.; MORENO, F. L.; QUINTANILLA-CARVAJAL, M. X.; SALCEDO, F. Rheological evaluation of gelation during thermal treatments in block freeze concentration of coffee extract. Journal of Food Engineering, Bogotá, v. 242, p. 76-83, 2019.

SOLANKI, H. K. et al. Development of microencapsulation delivery system for long-term preservation of probiotics as biotherapeutics agent. BioMed Research International, Patan, v. 5, p. 1-21, 2013.

SOUKOULIS, C. et al. Stability of Lactobacillus rhamnosus $G G$ in prebiotic edible films. Food Chemistry, Leicestershire, v. 15, n. 159, p. 302-308, 2014.

SUN,X.;CAMERON, R.G.;BAI,J.Microencapsulation and antimicrobial activity of carvacrol in a pectinalginate matrix. Food Hydrocolloids, Pierce, v. 92, p. 69-73, 2019. 
VOS, P. et al. Encapsulation for preservation of functionality and targeted delivery of bioactive food components. International Dairy Journal, Wageningen, v. 20 , p. $292-302,2010$.

YE, Q.; GEORGES, N.; SELOMULYA, C. Microencapsulation of active ingredients in functional foods: From research stage to commercial food products. Trends in Food Science \& Technology, Victoria, v. 78, p. 167-179, 2018.
YONEKURA, L. et al. Microencapsulation of Lactobacillus acidophilus NCIMB 701748 in matrices containing soluble fiber by spray drying: Technological characterization, storage stability and survival after in vitro digestion. Journal of Functional Foods, Loughborough, v. 6, p. 205-214, 2014.

ZAPATA, K., CORTÉS, F. B.; ROJANO, B. A. Polifenoles y Actividad Antioxidante del Fruto de Guayaba Agria (Psidium araca). Información Tecnológica, Medellín, v. 24, n. 5, p. 103-112, 2013. 